\title{
Collectors, investors and speculators: Gatekeeper use of audience categories in the art market
}

\author{
Erica Coslor ${ }^{1}$ \\ Department of Management and Marketing, University of Melbourne, Australia \\ Brett Crawford \\ Department of Technology Leadership \& Innovation, Purdue University, USA
}

Andrew Leyshon

School of Geography, University of Nottingham, UK

\section{Corresponding author}

Erica Coslor, Department of Management and Marketing, University of Melbourne, Melbourne, Victoria, 3010, Australia

Research was funded by the American Philosophical Society, University of Chicago Overseas Dissertation Fund, the University of Chicago Nicholson Center for British Studies, University of Chicago Markovitz fellowship and University of Melbourne Faculty of Business and Economics. Sotheby's Institute of Art, London, graciously allowed several weeks reviewing their Master's dissertations. This paper has benefitted from generous comments from both editors and peer reviewers, and insightful feedback from Douglas Creed, Cynthia Hardy, Sylvie Honig, Ed Hyatt, Melissa Kew, Brandon Lee, Steve Maguire, Yuval Millo, Michael O’Hare, Peter Frumkin, and Edward Lynch-Bell, and many others, with copyediting by Emma Nichols and Joel Barnes. 


\begin{abstract}
This research examines gatekeepers' categorization work to assess and sort audience members. Using a multi-sited ethnography and interpretivist qualitative lens, we explore how high-value art gallerists sort buyers via categories, but also encourage conformity with preferred audience categories, both for artistic consecration goals and to discourage disruptive speculation. Categories served as reference points, with preferred and problematic buyer categories providing a discursive socialization tool, but also informing gatekeeping strategies, for example, problematic behaviors and buyer categories led to value-protecting gatekeeping and exclusion, often justified in moral terms. Monitoring continued throughout the relationship, with decisions considered both fair and necessary for gallerists' professional practice. Gatekeeping decisions included long-term temporal considerations, prompting strategies including 'placement,' monitoring and audience recategorization. This extends gatekeeping beyond simply passing muster at the 'gate.' We also illustrate the dynamic and fluid nature of hidden categories, which provide gatekeepers with heightened abilities to punish perceived wrongdoing.
\end{abstract}

\title{
Keywords
}

Categories; buyer categories; gatekeeping; gallerists; market intermediaries; strategic placement; artistic consecration; punishment; duty of care assessments; value construction 
We only sell to people that we know and trust. If it is a seminal piece in an artist's oeuvre, then we only sell to certain trusted people... We do encourage new collectors, but at the same time it is difficult, as we need to trust them. We sell to people who will come to us before selling to anyone else (Contemporary art gallerist, London, quoted in Davis, 2005).

Organizational researchers frequently turn to social categories to understand markets, fields, and complex areas of social life (Bowker \& Star, 1999; Vergne \& Wry, 2014; Hannan, et al., 2019). Therein, numerous articles examine how audiences rely on categories to evaluate organizations, often with a focus on intermediary assessments of organizations and products (e.g. Durand \& Paolella, 2013; Pontikes \& Barnett, 2015; Durand \& Khaire, 2017), such as the value, boundaries and legitimacy of artistic movements and producers (DiMaggio, 1987; Khaire \& Wadhwani, 2010; Jones, et al., 2012; Cattani, et al., 2013). Rarely, however, do researchers pivot to explore how categories are deployed to sort through audiences. If categories shape the interface between organizations, intermediaries and audiences (Vergne \& Wry, 2014; Kornberger, et al., 2015), and are important for audience attention (Glynn \& Navis, 2013), we argue audience selection can also have distinct implications for perceived product quality, valuation, firm reputation and market function. For example, nightclub bouncers decide who passes the velvet rope (Rivera, 2010), consulting firms exclude particular clients (O'Mahoney, et al., 2013) and only some buyers are authorized to purchase human tissues (Anteby, 2010). Examining these undertheorized discretionary assessments can enrich existing work on the impacts of visible versus hidden categories (Washington \& Ventresca, 2004). We direct the social categories literature toward professional practices in audience categorization, including hidden gatekeeping by key market intermediaries. 
Gatekeeping is defined as the selection of who is 'in' or 'out,' assessing who is worthy to pass through a 'gate' (Lewin, 1947: 145). Audience members who pass muster are afforded access while those deemed unworthy are not. Gatekeeping typically features in creative industries research (Long Lingo \& O'Mahony, 2010; Foster, et al., 2011), but is useful for understanding categorization work performed by all sorts of intermediaries. We highlight gatekeeping as a complementary microfoundation of categories and categorization processes, adding to the growing, if limited, research at the intersection of social categories, intermediary audience assessments, and category boundaries in organization theory (Durand \& Thornton, 2018).

In this paper we bring together two disparate research themes, one exploring how intermediaries use categories to maintain clear social boundaries versus allowing ambiguity (Pontikes, 2012; Durand \& Paolella, 2013; Pontikes \& Barnett, 2015) and another focusing on gatekeepers' professional practices (Anteby, 2010; Rivera, 2010, 2015; Gustafsson, et al., 2018). First, building on an understanding that audiences are heterogenous (Durand \& Thornton, 2018), we consider the implications for categorical boundaries in reducing ambiguity. Second, as exemplified in the opening quote, gatekeepers may need to consider moral issues in professional practice (Anteby, 2010), echoing Durkheim's (1953) view of morality as a 'system of rules for conduct' unique to a given context. Here, professional practices of gatekeeping can be exercised on particular audience members to bring order and stability to the market (Bystryn, 1989; Rivera, 2010), including the enforcement of market expectations to suppress disruptive buyers (Ody-Brasier \& Vermeulen, 2014). Such gatekeeping is especially important in 
markets with high uncertainty (Peterson, 1997; Podolny \& Hsu, 2003; Foster, et al., 2011), where identifying trusted buyers, avoiding speculators, and stabilizing long-term valuation is paramount. Despite arguments that the deployment of intermediaries' professional assessments, and moral judgments in particular, are fundamental for sorting audiences (Anteby, 2010; Rivera, 2010; Gustafsson, et al., 2018), the ways in which these assessments can shape categories and their boundaries continue to receive scant attention. Consequently, we ask: How do gatekeepers sort audience members through categorical assessment, monitoring and other professional practices?

We explore this research question through a multi-sited ethnography, examining gallerist gatekeeping practices in New York and London. With roots in the sixteenth and seventeenth century artistic patronage system, the art market features stewardship and artistic legacy expectations, which can be undermined by particular buyers seeking shortterm financial gains. Through participant observations, interviews, and secondary data, we detail how gallerists made nuanced and hidden sorting decisions to distinguish between 'preferred' and 'problematic' buyers. Recategorization was possible later in the relationship, dependent upon behaviors and attributes. Our findings show nuanced gatekeeping decisions, especially with the newer investor category, recognized by some gallerists, despite longstanding resistance to speculation.

We offer three contributions. First, certain audience categories can be upheld as ideal, helping to channel behavior into desired actions though assessment and discourses, enhancing our understanding of category deployment through both categorization and discursive shaping of audiences. Second, while gatekeeping research considers initial 
categorical assessments, we advance the literature by examining later monitoring; gatekeepers in custodial roles may not only punish included customers for behaviors deemed inappropriate, but might later recategorize and blacklist (i.e., exclude) such buyers. Third, and finally, we build a process model of gatekeeping over the course of a relationship. Initially, sorting and 'placement' occurs with preferred buyer categories, new buyers are educated and problem buyers excluded, while monitoring, punishment and recategorization is pervasive. Our multifaceted model of category use in professional practice deepens understanding of relationships between buyer categories and gatekeeping, particularly for long-term value-construction goals in contexts with quality uncertainty and hidden categorization work.

\section{Gatekeeping and the Categorization of Audiences}

Gatekeepers are often key intermediaries, tasked with making categorical judgments, protecting boundaries and enhancing market order. Gatekeepers vary in form and focus, from individuals to networks across multiple levels (Peterson, 1997; Franssen \& Kuipers, 2013), who may focus on particular market areas and strategies (Bystryn, 1989). They work to uphold what Zuckerman (1999) referred to as categorical coherence, judging whether individuals, organizations, practices, and products belong in given categories (Ashforth \& Humphrey, 1997). Categories provide cues for gatekeepers' expert judgment (Rivera, 2015), with categories used to determine who: gains admission (Rivera, 2010); is granted permission (Reuber \& Morgan-Thomas, 2017), and; can be trusted (Podolny, 1994). Sorting may involve discretionary devices such as blacklists for punishment and discipline (Pontikes, et al., 2010). Penalties can be levied when buyers 
breach market expectations (Ody-Brasier \& Vermeulen, 2014), both to inculcate positive buyer behavior and punish transgressions (Leyshon \& Thrift, 1999).

We argue gatekeeping also encompasses discursive strategies. For example, gatekeepers convey categorical assessments more widely to facilitate exchange, influence perceptions and enhance value (Khaire \& Wadhwani, 2010; Cattani, et al., 2013; Koçak, et al., 2014; Durand, et al., 2017). Such strategies apply to audiences: discourses and stories are important for instilling positive buyer behavior, conveying market expectations and deterring unwanted behaviors. Categories thus become tools and resources for social actors to elaborate particular social identities- for themselves or others—often highlighting differences (Durand \& Thornton, 2018).

Much existing research focuses on highly visible categories, from environmental ratings to rankings (Kovács \& Sharkey, 2014; Sharkey \& Bromley, 2015), where the visibility of categories renders them useful to target audiences (Washington, 2004; Washington \& Ventresca, 2004). Far less is known about hidden categories that typically remain private in their deployment and equip gatekeepers with greater levels of discretion. Existing research on private categories underscores our incomplete knowledge of private category usage in gatekeeping (e.g. Pontikes, et al., 2010; Rivera, 2010). For instance, while discrimination is an illegal form of social evaluation, hiring practices behind closed doors nonetheless seek to identify unacceptable candidates to exclude, as well as highly valued candidates to prioritize (Rivera, 2015). Privacy in sensitive contexts including hiring, prize deliberation and other areas where gatekeepers might seek to 
sensitive sorting decisions that would be 'fraught with contention' if performed under public scrutiny (Quinn \& Munir, 2017: 115).

Another gap motivating our work relates to the understudied issue of temporality within the gatekeeping and categories literature. Lewin's (1947) classic work suggests that once gatekeepers let people, firms, and items pass through the gates, they tend to support those included, perhaps with further gatekeeping by actors at higher levels (Franssen \& Kuipers, 2013). For example, universities use categories to evaluate the suitability of proposed student organizations during formal approval processes (Coslor, et al., 2018); once approved, student clubs face lower administrative scrutiny. We know far less, however, about contexts where gatekeepers' responsibilities continue well past the point of admission, prompting examination of whether gatekeepers grant approval differently when considering the long-run implications of their sorting decisions. Gatekeeper scrutiny might also differ in contexts where categorical approval is enduring (Podolny, 1994; Long Lingo \& O'Mahony, 2010), versus contexts featuring regular review, such as firm ratings (Sharkey \& Bromley, 2015), or if troublemakers can be thrown out (Rivera, 2010). Work on cultural consecration aside (e.g. Allen \& Lincoln, 2004; Cattani, et al., 2013), the longer-term implications of category inclusion and exclusion have received scant attention, particularly when it comes to audiences. This perhaps relates to the dearth of studies on categories and gatekeeping that consider moral implications when it comes to categorical boundaries in professional practice, which we consider next. 


\section{Categorical Considerations in Gatekeepers' Professional Practice}

Gatekeepers are often embedded in formal and informal codes of practice, and many perform professional gatekeeping roles (Anteby, 2010; Rivera, 2010, 2015; Gustafsson, et al., 2018), adding additional responsibility. Professionalism includes upholding the integrity of one's office (Abbott, 1988), work historically considered a service to God and humankind (Weber, 1992). Aspects of professionalism and duty of care thus precede instrumental goals like profits. Despite arguments that erosion of ethics has diminished 'entrance into an office' (Weber, 1968: 69) from meaning a 'vocation' with a duty of care, echoes of these duties nonetheless remain in many professions.

A professional duty of care has implications for categorical boundaries. Despite positives of categorical ambiguity, blending and spanning (Durand \& Paolella, 2013; Pontikes \& Barnett, 2015), the benefits of relatively crisp boundaries are revealed by intermediaries enforcing authenticity and boundaries of cultural genres (Glynn \& Lounsbury, 2005; Jones, et al., 2012), and regulators being flummoxed by categorical ambiguity (Funk \& Hirschman, 2014). Emergent categories in particular create problems for assessing category attributes and membership (Hsu \& Grodal, 2015), and thus categorical boundaries. Categorical ambiguity in audience categories can be particularly problematic when it comes to duty of care. For example, therapists need to transfer clients due to conflict of interest, while animal breeders must exclude buyers suspected of animal cruelty. Duty of care assessments also entwine value in various ways, from legal issues of value damage to penalties levied for moral breach in markets, or restrictions of the exchange value of products (O'Mahoney, et al., 2013; Ody-Brasier \& Vermeulen, 
2014). This becomes significant when professional duty of care seeks to limit harms to both clients and market order. For instance, gallerists block customers who might damage artistic careers (Velthuis, 2005), exemplifying both moral and instrumental motives. We question what happens to categorical boundaries when audience gatekeeping decisions are made not just to avoid lower profits or future value, but to prevent harm to organizational reputations, market function, individual careers or human dignity. We find inspiration in work where moral judgments are attached to categories (Durand \& Vergne, 2015; Reuber \& Morgan-Thomas, 2017), often via assessment of actions and attributes implied by category membership and social performance (Ashforth \& Humphrey, 1997; Anteby, 2010). Nevertheless, research on gatekeepers' use of categories to perform moral assessments and sort audiences is limited. Overall, whether for instrumental, moral or multiple motivations, we view gatekeepers' concern with the long-term vitality of particular products and markets as an exciting context to examine the assessment of audience categories and their boundaries.

\section{Empirical Context: The High-Value Art Market}

We examined gatekeeper assessment of audiences and category boundaries in the high-value art market. In terms of structure, auctions are public, open to all buyers and sellers, comprising the main secondary (resale) market (Velthuis, 2005; Heath, 2013). The gallery system, in contrast, hosts the primary market (first-time sales). Characterized by private exchanges and long-term patronage, transactions between galleries, collectors, museums and individuals (usually brokered by gallerists) make up 50-60\% of the market by sales volume, with auctions comprising the remainder (Velthuis, 2005). Buying works 
from galleries to sell at auction - i.e. arbitrage - is a point of contention, especially in the short run. Auction prices underlie later valuations, with comparable works by the same or similar artists used to value unique items (Karpik, 2010; Coslor, 2016). Auction price instability can cause buyers to lose faith in the artistic value of the work (Velthuis, 2005), destabilizing an artwork's perceived significance. That is, price changes are both symbolic and interpretive, with an expectation that prices should not decrease (Velthuis, 2003). Meanwhile, art price appreciation encourages speculation and financial investment (Campbell, 2008) and an influx of new buyers with different motives threatens to destabilize prices further.

Gallerists use gatekeeping to bring order and stability to the market, given the complicated relationship between prices and valuation. In this unregulated market, gallerists both create the market for the artists they represent (buying and selling), and intervene to control price levels, temper speculation, and link seminal artworks with key tastemakers. A primary objective is to 'establish a firm market for their artists' as a means to build market stability via 'control of the biography of the work' (Velthuis, 2005: eg. 6-7).

\section{Methods}

Our three-year ethnography on art as an investment (Coslor, 2016; Coslor \& Spaenjers, 2016) examined gallerist practices in the high-value international art market, where artworks range from several thousand to millions of dollars. Our method 'followed the object' of art investment (Czarniawska, 2004). We thus focused on gallerist practices in two dominant art markets: New York and London. As the leading centers for 
international art market sales (Morgner, 2014) these cities host major art world institutions, while as financial centers, feature prospective investors. Initial exploration of the structure of this market highlighted the global and seasonal patterns of major auction sales, art fairs and gallery openings. This event-based context suited multi-sited ethnography (Marcus, 1995), a technique with growing popularity in organization studies because of its applicability to global markets and processes (Jarzabkowski, et al., 2015).

Data was generated from 34 ethnographic interviews and participant observation at 29 events, as well as numerous secondary documents (Table 1). Interviews were conducted with relevant actors (e.g., art fund representatives, gallerists), both opportunistically and through snowball sampling. Interviews at art fairs were especially useful, given our focus on difficult-to-access elites (Odendahl \& Shaw, 2002); galleries selected to show at juried international art fairs are deeply embedded in market practices. Interviews lasted between 20 minutes and several hours, featuring open-ended questions, with attention to art investment, gallerists' professional practices, perceptions of bad behavior, and refusals to sell to art investors. Participant observation at art events (auctions, panels, art fairs) traced art investment and gallerists as intermediaries, with art market panels noting professional concerns (e.g. 'Is the Killer Art Market Killing Art?'). Secondary sources included art market books (e.g. Lindemann, 2006) and 25 student Master of Art Business theses from Sotheby's Institute of Art, selected from a database search of 'art investment;' these included further interview data. Additional documents from events (auction catalogs, guides, flyers), newspapers and secondary sources 
enhanced examination of emergent topics, along with video transcripts of Art Dealers Association of America (ADAA) panels.

\section{***INSERT TABLE 1 HERE***}

From the beginning, the research included a focus on gallerists' gatekeeping practices, in part because in contrast to the measured responses typical of many professionals, gallerists' stock-in-trade storytelling revealed views on the most admirable — and despised — buyer practices. Gallerists not only oversee who is enrolled into buyer categories, but also socialize new collectors into preferred categories. Some buyer categories and behaviors were upheld as valorous, with others deemed worthy of punishment and exclusion. Practices in New York and London were generally consistent, in part because high-value gallerists - and some collectors - attend art fairs, auctions and events worldwide.

\section{Qualitative analysis}

Our analysis built on cultural anthropology methods (Bernard, 1988). We used interpretive thematic analysis (Corley \& Gioia, 2004; Delmestri \& Greenwood, 2016), synthesizing thick description into interrelated themes to identify patterns and commonalities. With an emphasis on shared beliefs, practices, customs and meanings, primary interviews with gallerists and relevant actors, along with interviews in secondary data, were analyzed to determine motivations and strategies for gatekeeping. Working iteratively between these data and our growing understanding, memos and diagrams helped crystallize coding. Successive review of key themes and data revealed key discourses related to art buyer categories, categorical pairings and groupings, category- 
tied actions and natural opposites. For example, gallerists often mentioned collectors in comparison to investors, while desired behaviors were typically contrasted with problematic behaviors.

An initial goal was understanding why some art investors were allowed to buysometimes welcomed — despite the general mistrust of financial motives by gallerists (see Velthuis, 2005). This led us to focus on the in vivo buyer categories, emerging from interviewees' own descriptions, allowing identification of preferred ('collectors,' 'investors') and problematic ('speculators,' 'flippers') buyer categories. Buyers categorized as preferred acted in ways judged appropriate by gallerists, while problematic buyer categorization indicated behaviors damaging to artistic careers. We focused on: refusal to sell (e.g. selective sales, trust, 'placement'); behaviors and attributes of collectors; behaviors and attributes of investors, particularly as distinguished from problem buyers; discursive category use and buyer socialization, and; strategies to deal with problem buyers. We systematically applied buyer categories across the data, a task requiring nuanced ethnographic interpretation. Idiosyncratic language use meant we had to review the context to understand correct meanings, going beyond keywords as a dealer might say 'speculator' to mean a legitimate buyer. This was especially significant because the investor category was in formation and not universally recognized; some gallerists lumped investors and speculators together as buyers to be avoided, meaning analysis required care to assemble the attributes constituting the legitimate investor, as opposed to undesirable speculators. We then focused on how buyer categories and 
gallerist gatekeeping practices related to one another. For example, a 'flipper' could be categorized as a type of speculator, leading to a gatekeeping strategy of blocking.

Through iterative refinement of these themes (e.g. Corley \& Gioia, 2004), we systematically recoded buyer attributes and behaviors, particularly those considered preferable or problematic by market participants, then assembled these into buyer categories, and finally preferred versus problematic buyer types (Figure 1), which linked to particular gatekeeping strategies. Buyer categories and gatekeeping strategies were well-documented across multiple sources (e.g. Table 2).

\author{
***INSERT FIGURE 1 HERE*** \\ ***INSERT TABLE 2 HERE***
}

\title{
Findings
}

I Preferred buyers: Patrons, traditional collectors and strategic placement

The art world is built on a network of personal relationships that develop over time. A gallery is judged on its track record. Over and over again, the associations between dealers and collectors have had a vital impact on the making of art history.

(Adam Sheffer, Cheim \& Read, quoted in ADAA, 2007: 18)

The ideal client for a gallery was someone who would contribute to an artist's career. Rooted in the historical patronage system and patron-artist honor, this provided an idealtype for appropriate behavior. 'Their responsibility is first and foremost towards the artist. A good collector, like a good gallerist, tries to carefully promote an artist, take care of him (sic) and follow his career, and also to share his collection with the public' (art advisor, London, quoted in Baker thesis, 2007). Obligations towards artists and the public 
were shared by collectors: 'You want to be a good steward,' (Dallas collector Marguerite Hoffman, ADAA panel, Intimate Histories of Collecting).

Gallerists were thus concerned with 'placement' of work with established collections and collectors who would become stewards:

We hope that artists will get the best museums, biennials, the best art reviews, and the other steps that are required for them to achieve renown. In order to help this process, we must of course try to place their works in the collections of great museums, but also with certain private clients whose personal collections are well known and respected (gallerist Emmanuel Perrotin, quoted in Lindemann, 2006: 104).

Given the markers of artistic success, Perrotin identifies the ideal of respected collectors becoming recognized tastemakers, highlighting the aspirational and socializing use of the collector category, where the best collectors might take a consecrating role.

These attributes and behaviors provided a basis for forward-looking, valueenhancing gatekeeping, as stewardship was related to the current and future value of artwork (Robertson, 2005). Museums were valued, important for artistic consecration, but placing works with private collectors could be preferable at early career stages:

You think about the artists and what that will bring to them. Collections where they will make an impact. Put things into museums but [a] young artist's work enters the collection and suddenly the museum treats it like a rare Rembrandt painting and put[s] a moratorium on travel and then you can't borrow the painting because of factors determining or some space is shown to not have a high enough humidity level... [C]ollectors... They tend to get behind artists. They want to develop and help artists... (Gordon VeneKlasen, Director of the Michael Werner Gallery, ADAA panel 'Is the Killer Art Market Killing Art?').

A hallmark of preferred collectors was an absence of monetary focus, as least in theory, echoing an ideal that art is incommensurable with money (Velthuis, 2005). Much has been written about this type of collector, particularly in sociology (Becker, 1982; 
Velthuis, 2005). More revealing is to turn to other art buyers, particularly those with financial motives.

\section{Problem buyers: Speculators, flippers and dumpers}

We next turn to problem buyers, particularly 'speculators' interested in using art for financial gain, and concerns that art would be 'hidden' away in storage (e.g. Sokolowski interview). Gallerists especially worried about arbitrage—-buying artworks from galleries to sell at auction — which risked auction prices falling short of estimates, with negative impacts for the artwork and artist (Velthuis, 2003). The visibility of online auction prices increased concerns, particularly when pieces failed at auction and were publicly designated as ‘bought in’ (Coslor, 2016).

These risks were higher for newer works and less-established artists. One gallerist representing well-established artists rarely encountered this behavior, which was less of a problem if people sold at auction in 10 years, rather than three, allowing the work's value to become established (London gallerist interview, Frieze Art Fair). Other gallerists seemed relatively unconcerned about arbitrage between gallery and auction:

That's not so much a problem for us, because we typically split the sales price with the artist, but that has happened. If we find out about it, we might try to work out a better deal for the artist next time, or see if there's someone else who might be a better fit (gallerist interview, New York Armory Show).

Despite the relaxed attitude, we find a subtle gatekeeping strategy. The next time this buyer sought to purchase, the gallery might recommend different artists. 
Even worse than selling at auction without gallery consent were buyers who might try to 'flip' artworks, analogous to the practice of buying and quickly reselling houses for real estate investment. According to one gallerist, flippers:

... buy something and automatically try to resell it. And they don't understand that every gallery has the same price. You're not going to buy it from me and then turn around and sell it to a gallery with the same artist and make money, so they get nervous because they don't realize that, and then they put it on the secondary market [at auction], and then we have to go in and buy it back (Washington DC gallerist interview).

Flippers were a subtype of speculator, judged negatively because they risked destabilizing price levels while creating additional work and expense for gallerists. But the most problematic category was that of 'dumpers,' those who sold multiple works with no regard for the artist's career. Dumping flooded the market: multiple artworks by the same artist in circulation could decrease prices. In the case of major collectors dumping was the opposite of consecration, seriously damaging artistic careers. Consider the case of artist Sandro Chia: a serious breach of expected behavior occurred when collector Charles Saatchi 'disposed of all six of the paintings that he purchased. Saatchi gave the impression that he sold the works to "purge" the collection rather than to obtain money. Chia [had] proposed to buy back the paintings rather than permitting Saatchi to sell them to just anyone' (Urban, 2003: 32). But Chia's request was refused.

Speculators, flippers and dumpers were identified as buyer categories to be avoided. Avoiding buyer ambiguity due to duty of care concerns about artistic careers, as valuing aesthetics over profits, explain a frequent sense of resistance to financial 
investment in the art market. Surprisingly, some investors were deemed acceptable by many gallerists, despite frequent suspicion of buyers with financial motives.

\section{Emergent category: Investors}

Placement concerns and valuation impacts of visible auction prices help explain why art dealers historically discouraged investment activity, making 'a sharp distinction between 'right' and 'wrong' acquisition motives' (Velthuis, 2005: 6), privileging aesthetic motives. Yet our findings indicated gallerists were not necessarily against buyers profiting from the artwork, instead maintaining strong views about acceptable ways to profit. Placing work into museums or prized collections to consecrate an artist's career was the top goal. But even if buyers later sold the work, rather than donating it, buyers could earn acceptable monetary rewards through a steady increase in the value of an artist's work over time, particularly with stewardship practices to help build up this value.

These allowable ways to profit help to explain why some gallerists recognized an investor category, distinct from problematic speculators. This was most clearly shown in Loring Randolph's (2005) Sotheby's thesis, which noted financial motivation for collectors, investors and speculators, but distinguished investment as seeking long-term gains and potentially including aesthetic judgments. In contrast, speculating was 'buying art in the hopes of gaining a return, not from the non-pecuniary benefits of owning art but a monetary and gambling or risk satisfaction, in a short-term period... Speculation described in this manner threatens the stability of the art market' (37). Through a longterm view and 'formation of judgments' (37), Randolph's definitions suggested 
investment could be separated from disruptive speculation, and potentially acceptable. This emergent category of pure investors, including individuals, syndicates and large, professional organizations (Coslor \& Spaenjers, 2016), was grounded in academic research on diversification, with art as a portfolio hedge (Campbell, 2008), given longterm investment properties (Robertson, 2005). Investors could also have mixed motives: as explained by one art fund representative, about $40 \%$ of their clients were also interested in the art, whereas 'all are interested in the money' (art fund interview, London).

Nonetheless, some gallerists steadfastly rejected all art investors: 'We don't solicit them —it automatically leads to bad behavior. If I know you're going to take the piece to auction in a couple of years, why would I sell that to you?' (London gallerist, Frieze Art Fair, London). A more common, moderate view was skepticism that art investment would make money. Andras Szanto of Sotheby's Institute of Art raised market volatility concerns: 'We've seen this type of interest before, but then there's a crash and they disappear' (interview). A few gallerists welcomed investors, particularly in interviews conducted soon after the financial crisis, such as this one in early 2009:

Oh yeah. There was an article in the Wall Street Journal ... about art as an investment and they had an interview with our founder. But there are many different kinds of collectors. For those that do want to make money on art, we like to say that now is the best time to invest in art... because you can get a discount on the price (gallerist interview, New York Armory Show).

In actively supporting art investment, this gallerist categorized investors as a sub-type of collector - a less common view— but one showing the category's movement away from problematic speculators. 
While this warm reception for investors was not typical, there was reasoned acceptance of investors by many gallerists. Investors were less preferred than collectors, but unlike problem buyers, were presumed to be businesslike by gallerists who recognized this distinction. As pointed out by a New York gallerist—one with moderate views on investment — while it was not the gallery's focus, '[t]here are people out there who buy for investments, but they treat it like a business, not to live with [artworks]' (New York gallerist, International Fine Art Fair, New York). Several interviewees also differentiated art funds as especially unproblematic:

...I don't think anyone has a problem with the [funds]. [It's investors] putting money into a common [pool]. The people who are investing in the [funds] don't have time to do a hands-on speculative hobby, which a lot of finance guys are doing - it's a hobby for them. They thought it was cool ... [Whereas] no one has problems with the [funds]. That is just people putting their money in and having specialists buy the work (Washington DC gallerist).

This quote highlights the advantage of ethnographic research in picking up nuanced understandings. We see this gallerist's view that speculators were tolerated whereas art funds were completely acceptable. Additional examination highlighted how art experts working for art investment funds often had the same or similar education and experience as gallerists, with training in prestigious institutes like the Courtauld Institute of Art. As knowledgeable art market insiders, these experts were trusted to act in ways ensuring future value.

The comments of investors themselves also illuminated shared understandings of what constituted an art investor. This was an active process, with efforts to 'fit' into this market and gain acceptance, and not 'try to manipulate the market' (art fund interview, 
London). Investors might also circulate the work in the same way as collectors, as seen in the British Rail Pension Fund's investment in art in the 1970s and 1980s. Susan Adeane, formerly Group Company Secretary for the Railways Pension Trustee Company (RPTC), played a role in the British Rail Pension Fund's investment in art and collectibles. She noted the importance of loaning out artworks: 'that was partly commercial, and it was also [that] we deliberately targeted some of the national institutions and some of the galleries in smaller towns which have big railway connections. So York City Art Gallery, and Doncaster Museum' (interview). As one of the four directors of the group making decisions about the art collection in the last 10 years of its existence, Adeane suggested that if British Rail was an investor, it was also a patron, treating artwork as a resource to be shared with the public.

Investors also played a useful role with what we term 'shadow placement.' Echoing the strategic role of 'placement' with prominent collectors helping to add value, investors provided gallerists and collectors with a convenient way of privately selling off artwork. This was preferable to auctions at times when prices might fall short of estimates, creating a negative signal about an artist (art market advisor, gallerist comments). Moreover, high profile art collectors might prefer to 'conceal their errors to protect their reputation' (Robertson, 2005: 15). Investors could thus be integrated into gallery business models as another type of buyer, stimulating purchases and potentially injecting 'liquidity' into the market (art market advisor, London; Tokyo gallerist, Frieze Art Fair, London). 
For gallerists who recognized a distinction between speculators and investors, investors seemed to play a useful market role. Investors displayed stewardship behaviors like collectors, helping to develop monetary value. They worked with gallerists: loaning out work, promoting artists, actions that could help to increase the perceived art-historical (and monetary) value. When it came time to sell, preferred investors worked together with gallerists, to mutual benefit. The investor category was newer than traditional collectors' roots in the artistic patronage system, but unlike profiteering speculators, shared obligations and knowledge about the art market, perhaps building artistic recognition that could translate into monetary value. Buyers from art investment funds in particular seemed to fit existing market needs, with professional practices and matching temporal goals, plus the ability to quietly help dispose of collections. But if gallerists preferred certain categories of buyers, we must examine additional gatekeeping strategies.

\section{Controlled allocation and strategic placement}

You can't walk into Victoria Miro, [a prestigious contemporary gallery in London] and go, 'I'd like [to buy] this.' ...they'll say, 'Well, first of all, we've sold out this show a month before we put it up. Second of all, there's a two-year waiting list for this artist's work. And third of all, who are you? Can we have your name?' (artist Henrik Potter, also manager of the Free Art Fair, London).

Bringing in new buyers was a risk for gallerists. Assessing the type of buyer required guesswork: would they become a desirable tastemaker or a destabilizing speculator? Unlike strategic placement with recognized collectors, assessment was also difficult because new buyers often lacked knowledge of art market rules, meaning they could 
unintentionally exhibit problematic behavior. For example, buyers were generally expected to give the original gallery 'rights of first refusal' should they want to resell the work, because as market makers, gallerists knew potential buyers. Even for auction sales, gallerists wanted a chance to inform collectors of the artist to help ensure a reasonable hammer price; private sales were preferable where there was a risk that auction prices could fall short of estimates. Hence, the initial gatekeeping task of a gallerist was to decide whether they actually wanted to sell to a new buyer, given the risk of a buyer not becoming a solid collector, well versed in art world expectations, but a problematic speculator.

Gallerists were able to make this initial, sensitive categorical assessment that would determine if buyers were 'in' or 'out' (Lewin, 1947) because they are not obligated to tell prospective buyers what they have for sale, nor are they obliged to sell; the art market is unregulated. An unknown buyer could offer a prominent gallery several times the price of a painting, and the gallerist might not only refuse to sell, but also take offense, given existing waiting lists for artworks and a preference for buyers who will appreciate and hold the artwork (summarized from comments by Roland Augustine, director of the Luhring Augustine Gallery, ADAA panel 'Intimate Histories of Collecting'; echoed by other gallerists).

Controlled allocation practices facilitated artistic value construction, with a preference for strategic placement with recognized collectors and tastemakers as the preferred buyer category. With historical precedent for gallerist gatekeeping going back 
at least as far as the Impressionist Salon period (interview with art professor Elaine A.

King), placement was seen by dealers as fair and necessary:

People laugh at this whole notion of us saying that we 'place' work instead of selling it ... But in fact that's what we try to do. We want the work to go to people who are as serious about the work as we are. And that job is probably only going to become more difficult (New York gallerist Jeffrey Dietch, quoted in Kennedy, 2010).

Even with known collectors, various considerations mattered in allocating artworks, as noted by contemporary gallerist Marianne Boesky:

Let's say in the next Barnaby Furnas show we have six paintings available, and we have sixty people who want them - anyone who is willing to donate to a museum that wants the work will get priority. ...After that's done, then we'll go back to people who've been waiting for a long time and who have been especially supportive of the gallery over time (quoted in Lindemann, 2006: 35).

Here was an active prioritization of long-term stewardship to decide who would be allocated artwork by prominent artists. Eventual museum donations were prioritized, along with fairness in honoring waiting lists and longstanding gallery supporters. Sorting was particularly difficult in boom times, when gallerists wanted to select the best collectors:

Most dealers I know well struggle all the time with having an exhibition of an artist having eight works to sell and having 50 people who want to buy it, and have 35 people who are established, credible, thoughtful collectors... And a good dealer is someone whose principal commitment, regardless of how much money is out there, whose commitment is to the artist... to develop a healthy and sustainable career. So where to place it, how to make it move into the world, how to keep happy those people who were dissatisfied but were equally worthy... These pressures are not pleasures (Allan Schwartzman, art advisor and panel moderator, New York, ADAA 'killer art' panel).

Placement concerns sometimes came from artists:

... I sometimes go in and say, like, 'Please sell this to a museum, because this is my favorite painting and I feel this would-' [or] ...on the last show 
[I said] 'This painting I'm even reluctant to sell it to anyone, because I love it so much. I want it to go to a place that's a museum... please try to putget it there.' (artist Amy Sillman, ADAA Collector's Forum: Artists and Dealers: Creative Partnerships).

Another pattern of controlled allocation saw dealers buying their own artists' work at auction, to reallocate to preferred collectors (or sometimes investors). For example, bad behavior by an artist might require 'buying back' the work:

...we did have a case of one artist putting her work at auction without our permission. Which was just silly, because I found out about it, bought the piece and then sold it to a museum for two times what I bought it for, and she would have gotten more money if she'd brought it to me (gallerist, New York Armory show).

Buying back artworks by their artists at auction was a way to stabilize prices and recapture control of the artwork, but gallerists disliked having to do this. It might send a bad signal and was expensive, especially for works by popular living artists selling for millions of dollars. This might maintain prices by limiting supply, as one London gallerist noted: '[y]ou also get dealers buying for their clients at auction and dealers buying works of their artists back to keep prices up. We don't do that though' (quoted in Randolph, 2005). Although buying back work was a common practice, it was considered by some dealers to be underhanded, or an indicator that an artist's prices were too volatile, perhaps explaining why the gallerist distanced herself from this practice.

Many people disliked the secrecy of controlled allocation, including some from the art world. 'The stock market is much more democratic ... No one knows who's buying. All they want is my money ... [In the art market] there are certain works you can't have. There's this underbelly' (Elaine A. King interview). Tom Sokolowski, then director of the Warhol Museum, and previously a curator for the Grey Art Gallery at New 
York University, was also critical of gallerists falsely indicating that an exhibition was sold out, a common gatekeeping strategy. However, he also recognized positive reasons for controlling who was able to buy the work: 'Well, some [gallerists] are reputable, they want it to be going to people who they know are sensitive [to the careers of artists], who aren't going to dump something, [and] who do ultimately give the work to museums.' Gallerists working seriously for their artists wanted to ensure the buyer would be a longterm collector — not someone who recently came into money and might end up 'dumping' the work through poorly timed sales, or perhaps literally throwing away unsold artworks. 'And you know, that sort of thing has happened, certainly' (Sokolowski interview).

Controlled allocation encompassed several distinct gatekeeping practices (placement, allocation to good collectors, waiting lists, refusal to sell, buying back). With new buyers, gallerists worked to avoid buyers in the problematic speculator category by looking for the connoisseurship and aesthetic sense expected of collectors. Controlled allocation was not universally appreciated, but seen by gallerists as fair and necessary: fair in that placement enhanced artistic careers through recognition and consecration, and; necessary to rule out speculators, who might lower auction prices or create volatility, with knock-on valuation impacts for the artist.

\section{Strategies to socialize new buyers}

As noted, new buyers were risky. Expectations about artistic stewardship surprised buyers expecting first-come, first-served exchange, and regulated financial markets. The art world was also growing, exacerbating this problem: 'In the last 40 years the art world has gotten something like 100 times bigger than it was' (Amanda Sharp, 
Co-Director of the Frieze Art Fair, London, ADAA 'killer art' panel). As an unknown quantity, new buyers might turn out to be stewards of artistic careers or problematic speculators, perhaps without realizing it.

Expectations of buyers were not always obvious, meaning socializing new entrants into the expected duties of collectors (or investors) was required. Gallerists relied on formal and informal strategies to convey and enforce the expectation that buyers were entrusted with the artwork and, as such, had certain obligations. These expectations were sometimes made explicit, for example through agreements that buyers return work to the original gallery should they wish to resell. But gallerists often preferred socialization strategies, conveying norms of good collectors (and investors) through relationships:

Well, we don't evoke the 'right' of first refusal, because it's not a 'right.' Our clients choose to come back to us to sell a piece because we have developed a positive relationship with them. You want to place the works with good people and collections which will better serve the interests of your artists. We have strong relationships with people and ultimately as a financial concern, if they wish to re-sell a piece they recognize they will have a better chance of doing so through us. These things are based on trust (London gallerist, quoted in Randolph, 2005: Gallery selling artworks priced from several thousand to millions of pounds).

This gallerist's emphasis on trust indicates limits on what a client might do with the artwork. Trust seemed to be the crucial element, as in another gallerist's comments about rights of first refusal: 'No, that is something that is impossible to enforce. We want our clients to trust us because we trust them' (London gallerist, quoted in Randolph, 2005). A gallerist's goal was a long-term, trusting client relationship: 'We always try to be helpful. What we ideally want is a 30-year ongoing relationship with clients' (London gallerist interview, Frieze Art Fair, London). 
Not only were gallerists categorizing buyers for inclusion or exclusion, they might need to shepherd buyers toward preferred behaviors (i.e., 'educating' buyers). This was a sales tactic, but also a careful socialization process, seeking to inform new buyers of expected behaviors and discourage disruptive speculation. Shaping people to fit desired buyer categories was exemplified in galleries helping collectors build collections over time. These techniques could be used with both collectors and investors. But given the potential risk of speculation for those with financial investment motives, additional techniques might be required, including disciplinary strategies.

\section{Gallery discipline strategies for problem buyers}

Controlled allocation of artwork to trusted buyers helped gallerists to avoid problems, but bad behavior persisted, perhaps from miscategorized speculators or collectors' financial problems motivating sales. Problem buyers engendered various responses by gallerists, of which three were particularly important. First, gallerists practiced active sorting of even trusted collectors, often via the waiting list, as seen in the ADAA guide for collectors: 'Dealers appreciate clients who turn to them when re-selling, and are more likely to offer these collectors important works in the future' (ADAA, 2007:

20). Sorting was based on desired behavior, such as philanthropy:

Museums and non-profit spaces commonly request curatorial advice from dealers and ask for help in locating works the institutions wish to borrow for exhibition... Collectors who understand the custodial relationships inherent in caring for and lending their art to important exhibitions will often be treated more favorably by the dealer and the artist (ADAA, 2007: 19). 
Second, bad behavior might require buyer recategorization. This could be due to initial miscategorization or collector hardship: 'In the good times, you can control the market. In the bad times, some people become desperate, and then they'll sell things they wouldn't otherwise' (London gallerist, Frieze Art Fair). Third, the ultimate penalty was for the gallery to drop a client and blacklist them. When asked '[what] if someone buys work from you and sells it at auction quickly?' an interviewee replied, 'We never sell to them again. And the art world is incestuous, we all know each other. It's a small world' (London gallerist, Frieze Art Fair, London). Gallery coordination made it possible to exclude buyers from new works by their artists, with blacklistings likely to spread in the small world of the art market. We were told about an East Coast collector blacklisted by the Gagosian gallery in New York, whose attempt to flip a piece at Sotheby's required Gagosian to buy back the work at auction.

\section{Discussion}

Categories are central to how audiences understand organizations (Pontikes \& Barnett, 2015). We find gatekeepers also rely on categories to understand and sort audience members, using multiple strategies to produce long-term value and duty of care towards their artists. Due to gallerists' capacity to exclude through sorting, both preferred and problematic audience categories featured prominently. This not only adds to organizational studies in creative industry contexts (Long Lingo \& O'Mahony, 2010; Jones, et al., 2016), and work on careers and professionals (Rivera, 2015; Gustafsson, et al., 2018), but advances understanding of the hidden life of categories. 
Preferred buyer categories and discourses: Collectors and the emergent investor category

First, gallerists relied on categories to sort through audiences in pursuit of preferred buyers, akin to research on hiring practices (Rivera, 2015). Buyers, however, were not just sold artwork, but expected to become stewards. 'Placing' artwork with known tastemakers who would later donate to museums or help sell artworks avoided the risks of speculation. Incentives included benefits accruing from museum consecration, i.e. gatekeepers at higher levels (Allen \& Lincoln, 2004; Franssen \& Kuipers, 2013), and negating problematic price volatility (Podolny \& Hsu, 2003; Velthuis, 2003). Gallerists sought 'stewards' who would help develop the work through 'custodial' relationships, prominent collections and eventual donations to museums. Priority was granted to known buyers who could be trusted, especially for key artworks and emerging artists. Collector and investor categories, in particular, exemplified the long-term stewardship expectations of the artistic patronage system and related categorical attributes of esteemed buyers. We find that gatekeeping includes long-term temporal considerations, highlighting how sorting decisions go well beyond the entry hurdle. Gatekeepers consistently examine whether audience members can be trusted and anticipate their future behavior and likely impacts on careers and reputations.

However, emergent categories are difficult for intermediaries to assess (Hsu \& Grodal, 2015), as seen with investors. Collectors and investors differed in their goals, underscoring how different forms of value pertain to different audiences (Durand \& Thornton, 2018). The collector category was rooted in historical expectations of 
connoisseurship, taste, and procedural issues (e.g., loaning out work). The investor category, however, carried art market idiosyncrasies and financial market expectations, showing the development of shared meaning in the category (Khaire \& Wadhwani, 2010; Koçak, et al., 2014). Echoing the stewardship duties of collectors, this new category built acceptance through recognized practices (Segal \& Lehrer, 2012). Being emergent, the investor category was not universally recognized, but carried behavioral expectations about working with gallerists in predictable, businesslike ways. This included the ability to buy collections quickly and privately ('shadow placements'). It is also likely the financial crisis had prompted pragmatic reassessment of investors, as in research where market logics gain acceptance through shifting external contexts (Glynn \& Lounsbury, 2005). Additionally, both collectors and investors showed a longer-term focus, highlighting another aspect of temporal matching.

Buyer categories also helped to socialize and educate new buyers, providing a positive template and heroic narrative — or sometimes the opposite—channeling buyers toward preferred categories. This follows the generative, identity-formation role of categories in organizations and markets at the macro level (Glynn \& Navis, 2013; Durand \& Thornton, 2018), complementing work on discourses of expert categorization and judgment (Bowker \& Star, 1999; Glynn \& Lounsbury, 2005). Discursive deployment of categories illustrated how gatekeepers might intentionally refer to preferred buyers, for example, gallerists' valorization of collectors gaining recognition for artistic stewardship. Similarly, some gallerists endorsed investors as appropriate, differentiated from problematic 'speculators,' using discursive socialization to convey expectations about 
suitable investment practices. Our findings thus contribute to socialization and conformity mechanisms via discursively deployed categories.

Our focus on buyer categories also extends work on categories as reference points for judging appropriate client behavior, relating to underlying behaviors and attributes as foundations of audience categorization (Anteby, 2010; Reuber \& Morgan-Thomas, 2017). This underscores the importance of morality in categories research. The ability to assign buyers to categories based on professional judgments of expected behavior differs from existing socio-cognitive sorting research (Pachucki, 2012) due to being paired with a socializing ability to use stories about heroes and villains to shape audience category participation (Durand \& Thornton, 2018). These moral attributes of category definitions indicate the presence of a clear normative divide between included and excluded buyer categories, contrasting with contexts where categorical ambiguity or blurring is beneficial (Durand \& Paolella, 2013; Pontikes \& Barnett, 2015). This illustrates how moral considerations play an important role as gatekeepers sort through audience members. Nevertheless, though gallerists act in ways deemed morally justifiable for duty of care, this could be interpreted as discriminatory. Future research should consider the affordances granted by the hidden life of categories when it comes to inequality.

Trust but verify: Relational monitoring once past the 'gate'

We also advance categories research exploring how actors combat threats (Anteby, 2010; Rivera, 2010; Ody-Brasier \& Vermeulen, 2014), first by showing how gatekeepers evaluate the fitness of audiences early on, often at the point of entry (Rivera, 2010), and second, by working to exclude actors who might represent a risk long before 
they become manifest: problem buyers - especially 'flippers' and 'dumpers'—were excluded before they became a destabilizing problem for artworks or artists. Much like the shaping role of intermediaries who enable only certain types of commodification and profit (Podolny, 1994; O'Mahoney, et al., 2013), art dealers excluded certain forms of monetary gain through categorization work.

Given the categorical ambiguity of buyers over time, we found sorting assessments were made continuously. To discourage problematic buyers, categories became a disciplining device (Schneiberg \& Berk, 2010), involving initial refusal to sell, and punishments for established clients. Gallerists might punish bad behavior even if they stood to profit, with professional reputation trumping excessive profit-seeking (Rao, et al., 2001). We thus theorize a continuum for later punishments. Smaller issues prompted lighter discipline using sorting and prioritizing: buyers might be offered less prominent works or a longer wait for new work. Larger issues prompting buyer recategorization allow us to study punitive gatekeeping strategies later in the gallerist-buyer relationship. For example, arbitrage behavior saw established collectors recategorized as problematic 'flippers,' carrying associated penalties. This finding enriches understandings of mechanisms to ensure categorical and market compliance (Zuckerman, 1999; Durand \& Paolella, 2013; Ody-Brasier \& Vermeulen, 2014), demonstrating important categorical expectations at later relationship stages, and continuing duty of care (Anteby, 2010; Rivera, 2010).

These discretionary measures enhance understanding of the hidden uses of private categories and less visible category uses, contrasting with existing work on the impacts of 
visible categories (Washington \& Ventresca, 2004; Kovács \& Sharkey, 2014; Sharkey \& Bromley, 2015). We add important nuance to the hidden life of categories, moving beyond binary labels of hidden or visible by, instead, capturing the dynamism associated with publicly visible categorization work versus decisions that remain hidden. Future research should further examine hidden assessments, especially in contexts with ongoing monitoring of both positive and negative behaviors. With initial exclusionary gatekeeping — not necessarily visible to potential buyers — and later sorting via private waiting lists or blacklists circulated only among gallerists, we also show audiences being sorted in different ways at different points throughout relationships, which we theorize next.

\section{A process model of gatekeeping and relational monitoring}

Controlled allocation was motivated by two major forces: building artistic careers and concerns about disruptive buyers (Podolny \& Hsu, 2003; Karpik, 2010; Coslor, 2016). They formed opposite ends of a complex decision hierarchy, extending knowledge of the categorical elements of the value-shaping role of gatekeepers. Preferred and problematic categories and behaviors provided justification for gatekeeping decisions. Sorting decisions were deemed fair and necessary, and the art market's unregulated status allowed gallerists to privately make discretionary categorical assessments about preferred and problematic buyers.

We theorize an ongoing process of gatekeeping throughout the relationship (Figure 2), with initial selection and education, monitoring and later punishments or recategorization. Artistic consecration goals engendered active relationship-building with 
collectors to enhance value, focusing on stewardship, with artworks 'placed' with collectors for long-term benefit, adding to cultural gatekeepers' roles as co-producers, tastemakers and selectors (Foster, et al., 2011). Controlled allocation and socialization of buyers worked well in the initial stages, whereas punishments like blacklisting (Pontikes, et al., 2010; Ody-Brasier \& Vermeulen, 2014) and recategorization typically came later, emphasizing less visible but important gatekeeping strategies. Thus, in contrast to classical and recent gatekeeping work (Lewin, 1947; Rivera, 2010), our general process of audience gatekeeping features pervasive monitoring, allowing adjustments and buyer recategorization. This enhances understanding of gatekeeping sub-processes relating to long-term intermediary-audience relationships, with decisions to exclude potential buyers and, conversely, nuanced judgments about which works could be sold to 'included' buyers. Future research could further compare positive and negative sorting practices, as our study was more strongly focused on problem behaviors. More specifically, researchers might explore permeable categorical boundaries (Durand \& Paolella, 2013; Pontikes \& Barnett, 2015), as categorical ambiguity becomes more problematic in situations where categories are given moral assessments.

***INSERT FIGURE 2 HERE***

\section{Conclusion}

Our work contributes insightful links between categories and gatekeeping, particularly when it comes to the hidden life of categories and their use in sorting audiences. We find that professional gatekeeping practices are fundamental for understanding the microfoundations of categorization work performed by key 
intermediaries, with multiple strategies and a temporal focus involving duty of care and long-term value. This extends gatekeeping beyond passing muster at the 'gate,' examining audience categorization and professional practices by which gatekeepers relate behaviors and attributes to category boundaries. Further, the dual role of categorizing and discursive storytelling suggests a need for additional work on audience categories' discursive function and the role of heroic and villainous stories in professional practice.

We find that preferred and problematic audience categories feature prominently when exploring how gatekeepers rely on categories to understand and sort audience members. First, our attention to categorical boundaries enhances our understanding how ambiguity can be more or less problematic for different audiences (Pontikes, 2012; Durand \& Paolella, 2013). Second, our focus on gatekeeper professionalism adds important nuance to research on category uses on the micro level. This includes how long-term temporal aspects differ from gatekeeping research focused on initial selection criteria (Rivera, 2010; Coslor, et al., 2018). Our findings reinforce the importance of initial selection, but also highlight ongoing recategorization and exclusion of audience members as critical in the long-term, particularly if it is difficult to recategorize and exclude 'troublemakers' later (Rivera, 2010). As we focused on gallerists, future research might seek to integrate our multi-stage process with gatekeeping by other actors (Franssen \& Kuipers, 2013). Finally, we contribute to a growing body of research that highlights how the categorization of buyers for inclusion or exclusion requires gatekeepers to exercise their discretion (Podolny, 1994; Velthuis, 2005; Anteby, 2010; Rivera, 2010). Indeed, the hidden nature of category use aids decision-making critical for protecting markets and 
value. We have only scratched the surface of the hidden interplay between gatekeepers' assessments of audiences, long-term relational monitoring that underscores duty of care and the microfoundations of market intermediation. 


\section{References}

Abbott, A. D. (1988). The system of professions: An essay on the division of expert labor. Chicago, IL: University of Chicago Press.

ADAA. (2007). Adaa collector's guide. Art Dealers Association of America, (ed.). New York, NY.

Allen, M. P., \& Lincoln, A. E. (2004). Critical discourse and the cultural consecration of american films. Social Forces 82(3), 871-894.

Anteby, M. (2010). Markets, morals, and practices of trade: Jurisdictional disputes in the u.S. Commerce in cadavers. Administrative Science Quarterly 55(4), 606-638.

Ashforth, B. E., \& Humphrey, R. H. (1997). The ubiquity and potency of labeling in organizations. Organization Science 8(1), 43-58.

Becker, H. (1982). Art worlds. Berkeley: University of California Press.

Bernard, H. R. (1988). Research methods in cultural anthropology. Newbury Park, CA: Sage Publications, Inc.

Bowker, G. C., \& Star, S. L. (1999). Sorting things out: Classification and its consequences. Cambridge, MA: MIT Press.

Bystryn, M. (1989). Art galleries as gatekeepers: The case of the abstract expressionists. In A. Foster, and J. Blau (eds.), Art and society: Readings in the sociology of the arts: pp 177-189). Albany, NY: State University of New York Press.

Campbell, R. A. (2008). Art as a financial investment. Journal of Alternative Investments 10(4), 64-81.

Cattani, G., Dunbar, R. L. M., \& Shapira, Z. (2013). Value creation and knowledge loss: The case of cremonese stringed instruments. Organization Science 24(3), 813-830.

Corley, K. G., \& Gioia, D. A. (2004). Identity ambiguity and change in the wake of a corporate spin-off. Administrative Science Quarterly 49(2), 173-208.

Coslor, E. (2016). Transparency in an opaque market: Evaluative frictions between "thick" valuation and "thin" price data in the art market. Accounting, Organizations and Society 50), 13-26.

Coslor, E., Crawford, B., \& Brents, B. (2018). Whips, chains and books on campus: How emergent organizations with core stigma gain official recognition. Journal of Management Inquiry 0(0), 1056492618810812. 
Coslor, E., \& Spaenjers, C. (2016). Organizational and epistemic change: The growth of the art investment field. Accounting, Organizations and Society 55), 48-62.

Czarniawska, B. (2004). On time, space, and action nets. Organization 11(6), 773-791.

Davis, J. (2005). The new contributor: Experiential education in london's contemporary art market. (MAAB). Sotheby's Institute of Art, London.

Delmestri, G., \& Greenwood, R. (2016). How cinderella became a queen: Theorizing radical status change. Administrative Science Quarterly.

DiMaggio, P. J. (1987). Classification in art. American Sociological Review 52(4), 440455.

Durand, R., Granqvist, N., \& Tyllström, A. (2017). From categories to categorization: A social perspective on market categorization. In R. Durand, et al. (eds.), Research in the sociology of organizations: pp 3-30: Emerald.

Durand, R., \& Khaire, M. (2017). Where do market categories come from and how? Distinguishing category creation from category emergence. Journal of Management 43(1), 87-110.

Durand, R., \& Paolella, L. (2013). Category stretching: Reorienting research on categories in strategy, entrepreneurship, and organization theory. Journal of Management Studies 50(6), 1100-1123.

Durand, R., \& Thornton, P. (2018). Categorizing institutional logics, institutionalizing categories: A review of two literatures. Academy of Management Annals 0(ja), null.

Durand, R., \& Vergne, J.-P. (2015). Asset divestment as a response to media attacks in stigmatized industries. Strategic Management Journal 36(8), 1205-1223.

Durkheim, E. (1953). Sociology and philosophy: Free Press.

Foster, P., Borgatti, S. P., \& Jones, C. (2011). Gatekeeper search and selection strategies: Relational and network governance in a cultural market. Poetics 39(4), 247-265.

Franssen, T., \& Kuipers, G. (2013). Coping with uncertainty, abundance and strife: Decision-making processes of dutch acquisition editors in the global market for translations. Poetics 41(1), 48-74.

Funk, R. J., \& Hirschman, D. (2014). Derivatives and deregulation: Financial innovation and the demise of glass-steagall. Administrative Science Quarterly 59(4), 669-704. 
Glynn, M. A., \& Lounsbury, M. (2005). From the critics' corner: Logic blending, discursive change and authenticity in a cultural production system. Journal of Management Studies 42(5), 1031-1055.

Glynn, M. A., \& Navis, C. (2013). Categories, identities, and cultural classification: Moving beyond a model of categorical constraint. Journal of Management Studies 50(6), 1124-1137.

Gustafsson, S., Swart, J., \& Kinnie, N. (2018). 'They are your testimony': Professionals, clients and the creation of client capture during professional career progression. Organization Studies 39(1), 73-92.

Hannan, M. T., Le Mens, G., Hsu, G., Kovács, B., Negro, G., Pólos, L., Pontikes, E., \& Sharkey, A. J., editors. 2019 Concepts and categories: Foundations for sociological and cultural analysis. New York, NY: Columbia University Press.

Heath, C. (2013). The dynamics of auction: Social interaction and the sale of fine art and antiques. Cambridge, UK: Cambridge University Press.

Hsu, G., \& Grodal, S. (2015). Category taken-for-grantedness as a strategic opportunity. American Sociological Review 80(1), 28-62.

Jarzabkowski, P., Bednarek, R., \& Cabantous, L. (2015). Conducting global team-based ethnography: Methodological challenges and practical methods. Human Relations 68(1), 3-33.

Jones, C., Maoret, M., Massa, F. G., \& Svejenova, S. (2012). Rebels with a cause: Formation, contestation, and expansion of the de novo category "modern architecture," 1870-1975. Organization Science 23(6), 1523-1545.

Jones, C., Svejenova, S., Pedersen, J. S., \& Townley, B. (2016). Misfits, mavericks and mainstreams: Drivers of innovation in the creative industries. Organization Studies 37(6), $751-768$.

Karpik, L. (2010). Valuing the unique: The economics of singularities. Princeton NJ: Princeton University Press.

Kennedy, R. (2010). Lawsuit describes art 'blacklist' to keep some collectors away. The New York Times, Online ed. New York.

Khaire, M., \& Wadhwani, R. D. (2010). Changing landscapes: The construction of meaning and value in a new market category-modern indian art. Academy of Management Journal 53(6), 1281-1304. 
Koçak, Ö., Hannan, M. T., \& Hsu, G. (2014). Emergence of market orders: Audience interaction and vanguard influence. Organization Studies 35(5), 765-790.

Kornberger, M., Justesen, L., Madsen, A. K., \& Mouritsen, J., editors. 2015 Making things valuable. Oxford, UK: Oxford University Press.

Kovács, B., \& Sharkey, A. J. (2014). The paradox of publicity. Administrative Science Quarterly 59(1), 1-33.

Lewin, K. (1947). Frontiers in group dynamics: Ii. Channels of group life; social planning and action research. Human Relations 1(2), 143-153.

Leyshon, A., \& Thrift, N. (1999). Lists come alive: Eletronic systems of knowledge and the rise of credit-scoring in retail banking. Economy and Society 28(3), 434-466.

Lindemann, A. (2006). Collecting contemporary. Cologne: Taschen.

Long Lingo, E., \& O'Mahony, S. (2010). Nexus work: Brokerage on creative projects. Administrative Science Quarterly 55(1), 47-81.

Marcus, G. E. (1995). Ethnography in/of the world system: The emergence of multi-sited ethnography. Annual Review of Anthropology 24(1), 95-117.

McIntyre, M. H. (2004). Taste buds: How to cultivate the art market. London: Arts Council England.

Morgner, C. (2014). The art fair as network. The Journal of Arts Management, Law, and Society 44(1), 33-46.

O'Mahoney, J., Heusinkveld, S., \& Wright, C. (2013). Commodifying the commodifiers: The impact of procurement on management knowledge. Journal of Management Studies 50(2), 204-235.

Odendahl, T., \& Shaw, A. M. (2002). Interviewing elites. In J. F. Gubrium, and J. A. Holstein (eds.), Handbook of interview research: Context \& method: pp 299-316). Thousand Oaks, CA: Sage.

Ody-Brasier, A., \& Vermeulen, F. (2014). The price you pay: Price-setting as a response to norm violations in the market for champagne grapes. Administrative Science Quarterly 59(1), 109-144.

Pachucki, M. C. (2012). Classifying quality: Cognition, interaction, and status appraisal of art museums. Poetics 40(1), 67-90.

Peterson, K. (1997). The distribution and dynamics of uncertainty in art galleries: A case study of new dealerships in the parisian art market, 1985-1990. Poetics 25(4), 241-263. 
Podolny, J. M. (1994). Market uncertainty and the social character of economic exchange. Administrative Science Quarterly 39), 458-483.

Podolny, J. M., \& Hsu, G. (2003). Quality, exchange, and knightian uncertainty. Research in the Sociology of Organizations 20), 77-103.

Pontikes, E., Negro, G., \& Rao, H. (2010). Stained red: A study of stigma by association to blacklisted artists during the 'red scare' in hollywood, 1945 to 1960. American Sociological Review 75(3), 456-478.

Pontikes, E. G. (2012). Two sides of the same coin: How ambiguous classification affects multiple audiences' evaluations. Administrative Science Quarterly 57(1), 81-118.

Pontikes, E. G., \& Barnett, W. P. (2015). The persistence of lenient market categories. Organization Science 26(5), 1415-1431.

Quinn, Q. C., \& Munir, K. A. (2017). Hybrid categories as political devices: The case of impact investing in frontier markets. In, From categories to categorization: Studies in sociology, organizations and strategy at the crossroads: pp 113-150: Emerald.

Randolph, L. (2005). Upward market trends: A study on the evolutions of the contemporary art market in london through the insights of seven contemporary art dealers. (MAAB). Sotheby's Institute of Art, London.

Rao, H., Greve, H. R., \& Davis, G. F. (2001). Fool's gold: Social proof in the initiation and abandonment of coverage by wall street analysts. Administrative Science Quarterly 46(3), 502-526.

Reuber, A. R., \& Morgan-Thomas, A. (2017). Communicating moral legitimacy in controversial industries: The trade in human tissue. Journal of Business Ethics.

Rivera, L. A. (2010). Status distinctions in interaction: Social selection and exclusion at an elite nightclub. Qualitative Sociology 33(3), 229-255.

Rivera, L. A. (2015). Pedigree: How elite students get elite jobs. Princeton, New Jersey: Princeton University Press.

Robertson, I. (2005). The international art market. In I. Robertson (ed.), Understanding international art markets and management: pp 13-36). London: Routledge.

Schneiberg, M., \& Berk, G. (2010). From categorical imperative to learning by categories: Cost accounting and new categorical practices in american manufacturing, 1900-1930. Research in the Sociology of Organizations 31), 255-292. 
Segal, L., \& Lehrer, M. (2012). The institutionalization of stewardship: Theory, propositions, and insights from change in the edmonton public schools. Organization Studies 33(2), 169-201.

Sharkey, A. J., \& Bromley, P. (2015). Can ratings have indirect effects? Evidence from the organizational response to peers' environmental ratings. American Sociological Review 80(1), 63-91.

Urban, A. (2003). Manipulation and the contemporary art market: An examination of charles saatchi. (MAAB). Sotheby's Institute of Art, London.

Velthuis, O. (2003). Symbolic meanings of prices: Constructing the value of contemporary art in amsterdam and new york galleries. Theory and Society 32), 181-215.

Velthuis, O. (2005). Talking prices: Symbolic meanings of prices on the market for contemporary art. Princeton: Princeton University Press.

Vergne, J.-P., \& Wry, T. (2014). Categorizing categorization research: Review, integration, and future directions. Journal of Management Studies 51(1), 56-94.

Washington, M. (2004). Field approaches to institutional change: The evolution of the national collegiate athletic association 1906-1995. Organization Studies 25(3), 393-414.

Washington, M., \& Ventresca, M. J. (2004). How organizations change: The role of institutional support mechanisms in the incorporation of higher education visibility strategies, 1874-1995. Organization Science 15(1), 82-97.

Weber, M. (1968). Max weber on charisma and institution building: Selected papers, 1974 ed: University of Chicago Press.

Weber, M. (1992). The protestant ethic and spirit of capitalism. New York, NY: Routledge.

Zuckerman, E. W. (1999). The categorical imperative: Securities analysts and the illegitimacy discount. American Journal of Sociology 104(5), 1398-1438. 
Table 1: Ethnographic Corpus

\begin{tabular}{|c|c|c|}
\hline Data type & Quantity & Original data format \\
\hline \multicolumn{3}{|l|}{ Primary data } \\
\hline Interviews & 34 & $\begin{array}{l}\text { Event-based and formal interviews with gallerists, } \\
\text { artists and those involved in art investment }\end{array}$ \\
\hline Observational data & $\begin{array}{l}29 \text { events, including } \\
\text { auctions, fairs, gallery } \\
\text { openings, ADAA panels } \\
\text { and lectures }\end{array}$ & $\begin{array}{l}\text { Field notes: } 4 \text { journals of observational notes and on- } \\
\text { scene memos }\end{array}$ \\
\hline Event-related documents and reports & $\begin{array}{l}10 \text { coded } \\
\text { Over } 30 \text { collected }\end{array}$ & $\begin{array}{l}\text { Auction catalogs, fair guides, company documents, } \\
\text { reports collected during ethnography }\end{array}$ \\
\hline Surveys of attendees at London Art Fair & 50 & Paper forms \\
\hline \multicolumn{3}{|l|}{$\underline{\text { Secondary data }}$} \\
\hline $\begin{array}{l}\text { Sotheby's Institute of Art London MA in } \\
\text { Art Business dissertations }\end{array}$ & 24 & $\begin{array}{l}\text { Included a total of } 14 \text { full and } 30 \text { partial interviews, } 15 \\
\text { from gallerists. }\end{array}$ \\
\hline Videos & 10 & $\begin{array}{l}\text { 'America's Pop Collector,' BBC features, ADAA } \\
\text { Panels }\end{array}$ \\
\hline Books & 2 & Books on art dealers with interview data \\
\hline Secondary articles & Over 100 & Newspapers, magazines and online research \\
\hline
\end{tabular}


Table 2. Coding Examples for Buyer Categories

\begin{tabular}{|c|c|}
\hline Buyer Categories & Examples from the Data \\
\hline \multicolumn{2}{|l|}{ TARGETED BUYERS } \\
\hline \multirow[t]{2}{*}{ Stewards and Patrons } & $\begin{array}{l}\text { Stewardship of the artwork: At the highest levels, appropriate } \\
\text { buyers are those that can be trusted to provide safe custodianship } \\
\text { of the work, thereby maintaining its value and leaving it } \\
\text { accessible for loaning to exhibitions (McIntyre, 2004: 5). }\end{array}$ \\
\hline & $\begin{array}{l}\text { Donating to museums: Say we were both children with trust } \\
\text { funds. If we go into a gallery, more than likely they won't sell it } \\
\text { to you. There's no prestige, they won't get anything out of it. } \\
\text { They might sell it to me because I teach at Carnegie Mellon, and } \\
\text { hope that I'll eventually donate it to the Carnegie (Elaine A. } \\
\text { King interview). }\end{array}$ \\
\hline $\begin{array}{l}\text { Traditional Art } \\
\text { Collectors }\end{array}$ & $\begin{array}{l}\text { Art over money: The Traditional Collector, a pure aesthete, is } \\
\text { known for never considering the financial 'value' of their works } \\
\text { or the monetary amount they must part with to obtain the object } \\
\text { of their desires. For this camp, money is of no consequence } \\
\text { when the reward reaped from the ownership of a coveted work is } \\
\text { achieved (Davis, 2005, p. 2-3). }\end{array}$ \\
\hline \multicolumn{2}{|l|}{ NORMAL BUYERS } \\
\hline New Buyers & $\begin{array}{l}\text { Educating new buyers: ... when I was dealing with a lot of the } \\
\text { finance guys... they definitely put you on speaker phone and } \\
\text { you're sitting there with six guys, trying to explain to them the } \\
\text { difference between [the art market and other markets]. You } \\
\text { know, why they have to hold on for two years before they donate } \\
\text { it (Washington DC Gallerist). }\end{array}$ \\
\hline $\begin{array}{l}\text { Investors } \\
\text { (Included by Some } \\
\text { Gallerists) }\end{array}$ & $\begin{array}{l}\text { Gallerists open to investors: The art market has long been seen } \\
\text { as the last unregulated market... The emergence of art as an } \\
\text { 'asset class' has become a popular notion... Due to low returns in } \\
\text { the stock and bond markets investors searched for alternative } \\
\text { options in investing...financial models and terminology became } \\
\text { the language of choice when discussing art market returns } \\
\text { (Collier thesis, 2005). }\end{array}$ \\
\hline $\begin{array}{l}\text { Speculators } \\
\text { (Included by Some } \\
\text { Gallerists) }\end{array}$ & $\begin{array}{l}\text { Speculators as normal buyers: I'm happy that [the] price of art } \\
\text { has risen so enormously? However, it is taking away the } \\
\text { incentive of art lovers, and giving rise to a breed of speculators } \\
\text { that are buying art in a manner similar to stocks and shares. } \\
\text { There is therefore a whole new breed of art buyers with a very } \\
\text { different motive (gallerist quoted in Juneja thesis 2007). }\end{array}$ \\
\hline
\end{tabular}

PROBLEM BUYERS

Flippers

Avoiding flippers: In the primary market [flipping] is

something we are very, very careful about. And, if we suspect 
that to be the case then we really try and hold off from making those kinds of sales (ADAA "Committed Vision" Panel).

\begin{tabular}{ll}
\hline Dumpers & 'Dumping” multiple artworks: If investors dump an artist's \\
& work simultaneously, their effect on his/her career could be \\
& staggering and difficult to recover from (art advisor quoted in \\
& Gentile thesis, 2007). \\
\hline $\begin{array}{l}\text { Investors } \\
\text { (Excluded by Some }\end{array}$ & $\begin{array}{l}\text { Resistance to investors: ...gallerists don't like [investors], } \\
\text { because what [gallerists] want to do is to get their art in the } \\
\text { Gallerists) } \\
\text { hands of collectors who will enhance the value of their stable of } \\
\text { artists. They prefer to sell to Charles Saatchi or the Tate Modern } \\
\text { or whoever, rather to someone's investment fund, who will lock } \\
\text { it away where nobody will see it (Eckstein interview). }\end{array}$ \\
\hline $\begin{array}{l}\text { Speculators } \\
\text { (Excluded by Some }\end{array}$ & $\begin{array}{l}\text { Resistance to speculators: Speculation...threatens the stability } \\
\text { of the art market... In some cases, purchasing art is driven more } \\
\text { ballerists) }\end{array}$ \\
& by a desire for 'risk' and in others by 'maximizing utility' \\
(Randolph, 2005).
\end{tabular}


Figure 1. Coding Diagram

First-Order Concepts (Buyer Behaviors \& Attributes)
Second-Order (Buyer Categories)
Aggregate Themes
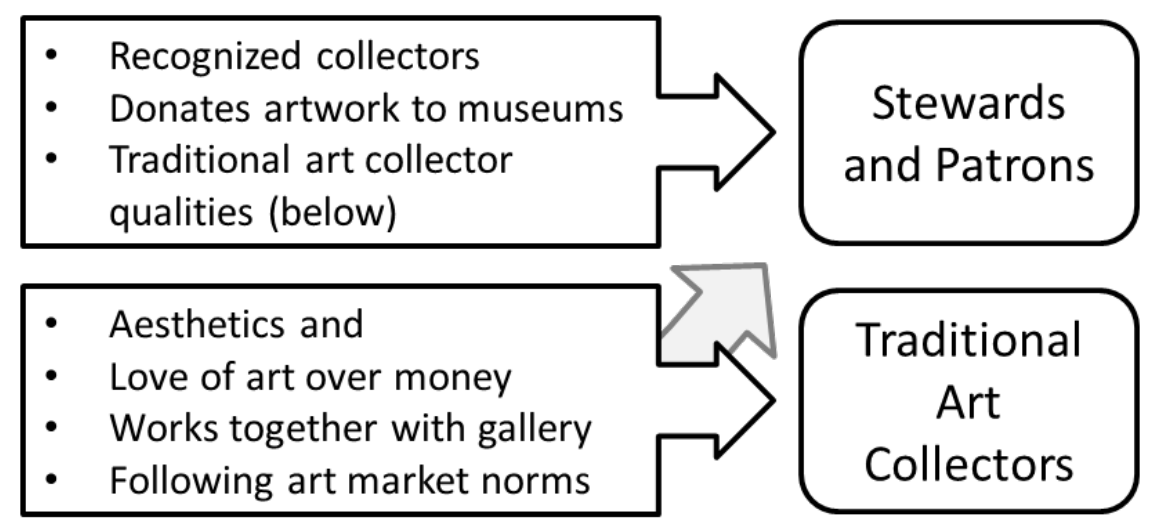

\begin{tabular}{ll} 
- & Aesthetic and financial goals \\
- & Art world glamor \\
& \\
\hline
\end{tabular}
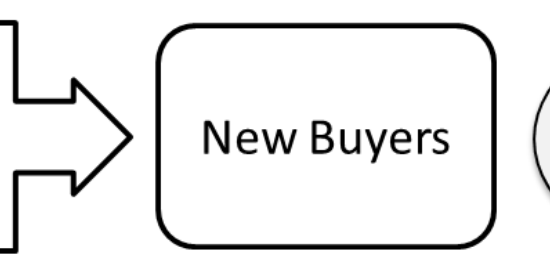

- Investment motives primary

- Long-term focus on value

- "Businesslike" behavior

- Following art market norms

- Money over art

- Short-term focus on profit, sometimes risk satisfaction

- Disregards art market norms

- Money over art

- Trying to "flip" artwork by buying at gallery and quickly selling at auction

- Disregards art market norms

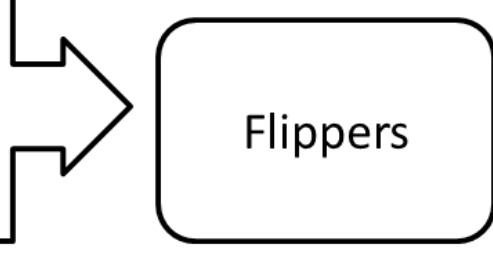

- "Dumps" multiple artworks by same artist onto the market at one time

- Disregards art market norms

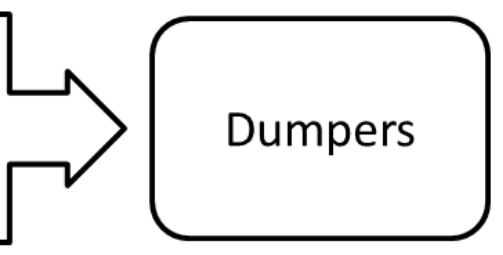

Targeted

Buyers

(Preferred)

Normal

Buyers

(Included)
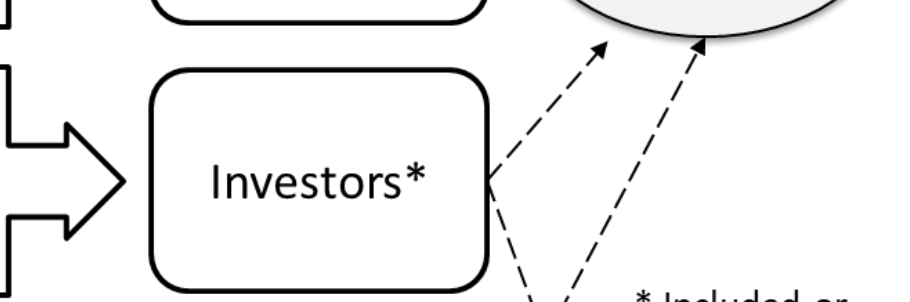
Figure 2. Initial and Later Sorting of Buyers

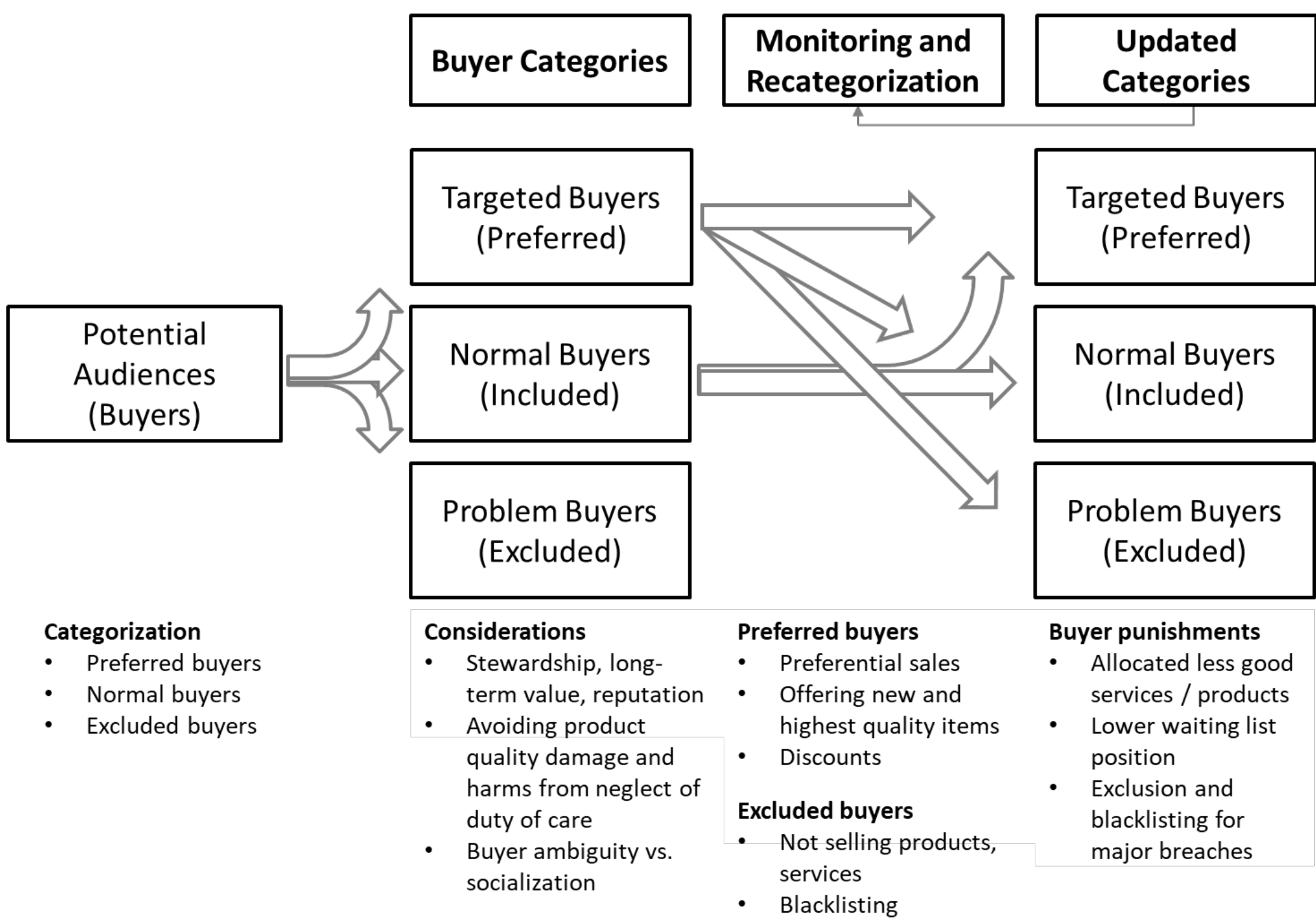




\section{University Library}

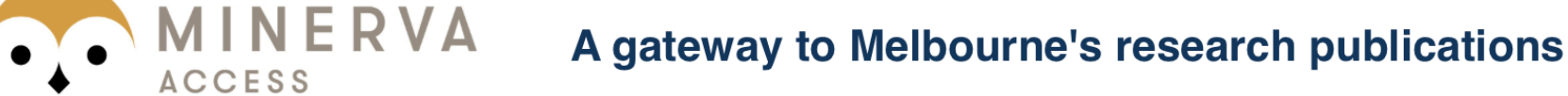

Minerva Access is the Institutional Repository of The University of Melbourne

Author/s:

Coslor, E;Crawford, B;Leyshon, A

Title:

Collectors, Investors and Speculators: Gatekeeper use of audience categories in the art market

Date:

2020

Citation:

Coslor, E., Crawford, B. \& Leyshon, A. (2020). Collectors, Investors and Speculators: Gatekeeper use of audience categories in the art market. Organization Studies, 41 (7), pp.945-967. https://doi.org/10.1177/0170840619883371.

Persistent Link:

http://hdl.handle.net/11343/241430 